INTERNATIONAL JOURNAL OF BANKING AND FINANCE

http://e-journal.uum.edu.my/index.php/ijbf

How to cite this article:

Toh, J. N., \& Khaw, K. L. -H. (2021). Fossil fuel price, carbon dioxide emission, and renewable energy capacity: Evidence from Asian developing countries. International Journal of Banking and Finance, 16(1), 79-96.https://doi.org/10.32890/ijbf2021.16.1.5

\title{
FOSSIL FUEL PRICE, CARBON DIOXIDE EMISSION, AND RENEWABLE ENERGY CAPACITY: EVIDENCE FROM ASIAN DEVELOPING COUNTRIES
}

\author{
${ }^{1}$ Toh Jia Ni \& ${ }^{2}$ Karren Lee-Hwei Khaw \\ Department of Finance and Banking \\ Faculty of Business and Accountancy \\ University of Malaya
}

2Corresponding author: karren@um.edu.my

Received: 3/11/2020 Revised: 11/12/2020 Accepted: 14/12/2020 Published: 30/1/2021

\begin{abstract}
This paper examined the impact of fossil fuel price and carbon dioxide $\left(\mathrm{CO}_{2}\right)$ emission on renewable energy, using a sample of 14 Asian developing countries from the years 2000 to 2018. Fossil fuel prices, mainly those of crude oil and coal, are positively related to renewable energy capacity. $\mathrm{CO}_{2}$ emission is also a positive driver, indicating the significance of environmental concern. The results were consistent for both the upper-middle-income and lower-middle-income countries. Between fossil fuels and $\mathrm{CO}_{2}$ emission, the positive impact of $\mathrm{CO}_{2}$ emission outweighed that of fossil fuels. From a policy perspective, this paper concurs the need to shift huge subsidies away from fossil fuels to renewable energy and to enforce a heavy tax on $\mathrm{CO}_{2}$ emission for a sustainable environment.
\end{abstract}

Keywords: Renewable energy, fossil fuel, $\mathrm{CO}_{2}$ emission, Asian developing countries.

JEL Classification: P28, Q30, Q42 


\section{INTRODUCTION}

This paper examines the impact of fossil fuel price and carbon dioxide $\left(\mathrm{CO}_{2}\right)$ emission on renewable energy capacity from the context of Asian developing countries. Asia has great potential for renewable energy resources, such as terrestrial wind and solar power in China and Vietnam, hydro and solar power in Malaysia, and geothermal energy in Indonesia and the Philippines. Nonetheless, the transition from non-renewable to renewable energy is slow. Asia accounted for 54 percent of the new renewable energy capacity in 2019; however, this capacity was mainly in China (International Renewable Energy Agency, 2019).

Excluding China, the potential in other Asian developing countries, many of which are lower-middle-income countries, is relatively untapped (Kariuki, 2018). One of the barriers to switching to renewable energy sources is cost disadvantage. Despite the decreasing price of renewable technologies, the production of renewable energy remains expensive and unaffordable for many developing countries as the renewable technologies have to be imported (Kariuki, 2018). Therefore, fossil fuels remain the dominant energy sources, although they are unsustainable given the rapid population growth, increasing energy demands, and volatile fossil fuel prices.

Hypothesis 1 examines the relationship between fossil fuel prices (oil, coal, and natural gas) and renewable energy. It is hypothesized that fossil fuel prices are positively related to renewable energy capacity on the basis of cost disadvantage. Higher fuel prices increase the burden on countries to continue supplying affordable energy to individuals and businesses. Globally, fossil fuel subsidies increased from \$287 billion in 2016 to $\$ 438$ billion in 2018 with increasing fuel prices. In 2019 , the fuel subsidies decreased by $\$ 120$ billion, largely due to decreasing fuel prices (International Energy Agency, 2020). Instead of increasing the fuel subsidies, it would be more sustainable to subsidize renewable investments so that renewable energy would be cost competitive as compared to non-renewable fossil fuels (Carley, 2009).

This study also determines whether environmental concern motivates the adoption of renewable energy among Asian developing countries. The major concern is the greenhouse gas emissions from the burning 
of fossil fuels. Although there is a decreasing trend of $\mathrm{CO}_{2}$ emissions, the effort is mainly driven by advanced economies (International Energy Agency, 2020). Excluding these advanced economies, about 80 percent of the 400 metric megaton increase in $\mathrm{CO}_{2}$ emissions in 2019 were due to Asian countries. Evidently, six of the Asian developing countries (Bangladesh, Myanmar, Nepal, the Philippines, Thailand, and Vietnam) are among the ten countries that most affected by climate change in the last two decades (Eckstein et al., 2019). Therefore, Hypothesis 2 posits that $\mathrm{CO}_{2}$ emission should be positively related to renewable energy capacity because it is critical to mitigate the adverse effect of climate change on achieving sustainability (Rustemoglu \& Andres, 2016).

This study contributes toward the growing literature on renewable energy in the following ways. First, it provides empirical evidence from the perspectives of Asian developing countries, where the motivations to adopt renewable energy among the countries, whether upper-middle-income or lower-middle-income countries, are significantly driven by fossil fuel prices and $\mathrm{CO}_{2}$ emission. The results agree with the common view that fossil fuel prices (e.g. Apergis \& Payne, 2014; Bird et al., 2005; Chang et al., 2009) and $\mathrm{CO}_{2}$ emission (e.g. Aguirre \& Ibikunle, 2014; Omri \& Nguyen, 2014; Sadorsky, 2009a; Salim \& Rafiq, 2012) are positively related to renewable energy. Second, this study concurs that renewable energy can be a substitute for crude oil and coal (Apergis \& Payne, 2014) and as a complementary energy source for natural gas because the latter is relatively clean as compared to crude oil and coal (Sadorsky, 2009a; Omri \& Nguyen, 2014). Third, environmental concerns are found to outweigh cost concerns. This paper argues that this is potentially due to the global pressure to decrease $\mathrm{CO}_{2}$ emissions that are currently rising. The rest of the paper is organized as follows: Section 2 details the methods used, while Section 3 is on the data, followed by Section 4 that discusses the results. Section 5 concludes the paper.

\section{METHODOLOGY}

This study examines the hypotheses by using the multivariate panel data regression model (Gozgor eta al., 2020; Przychodzen \& Przychodzen, 2020). In line with Gozgor et al. (2020) and Sisodia and Soares (2014), the random effects are controlled. The choice is further 
validated using the Hausman test. The empirical model is specified below:

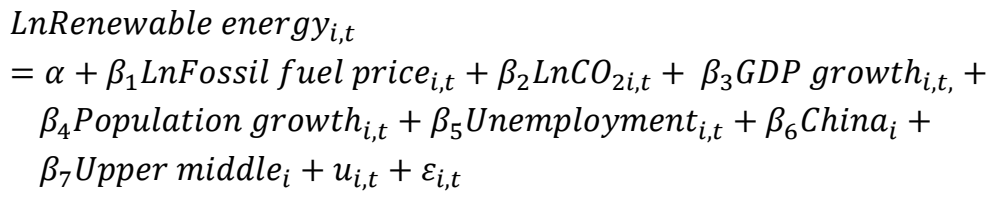

\section{Data}

A sample of 14 Asian developing countries were used in this study, namely Bangladesh, Bhutan, Cambodia, China, India, Indonesia, Laos, Malaysia, Mongolia, Myanmar, the Philippines, Sri Lanka, Thailand, and Vietnam. These countries were selected based on the availability of data. In total, there is a balanced panel dataset of 266 annual observations, spanning from 2000 through 2018. The dependent variable, renewable energy capacity, was collected from the International Renewable Energy Agency (IRENA) website. Figure 1 presents the average annual renewable energy capacity for the sample.

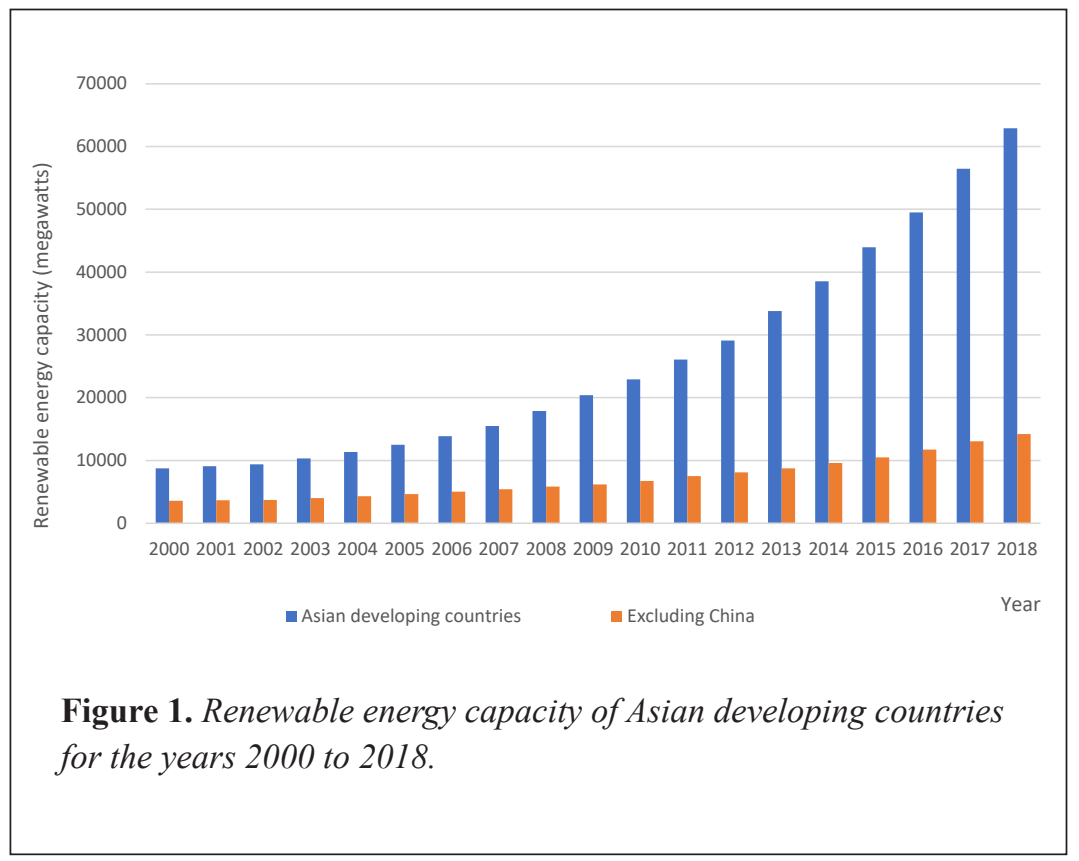


Over the years, the renewable energy capacity of these developing countries had increased from 8,728 megawatts in 2000 to 62,883 megawatts in 2018. This significant rise was mainly driven by China's renewable energy policies. Excluding China, the annual average renewable energy capacity showed a slower increase, from 3,565 megawatts in 2000 to 14,194 megawatts in 2018. Moving on, relatively close per capita values occurred even when China was excluded from the sample, as shown in Figure 2. This implied an underutilization of renewable energy sources among these developing nations.

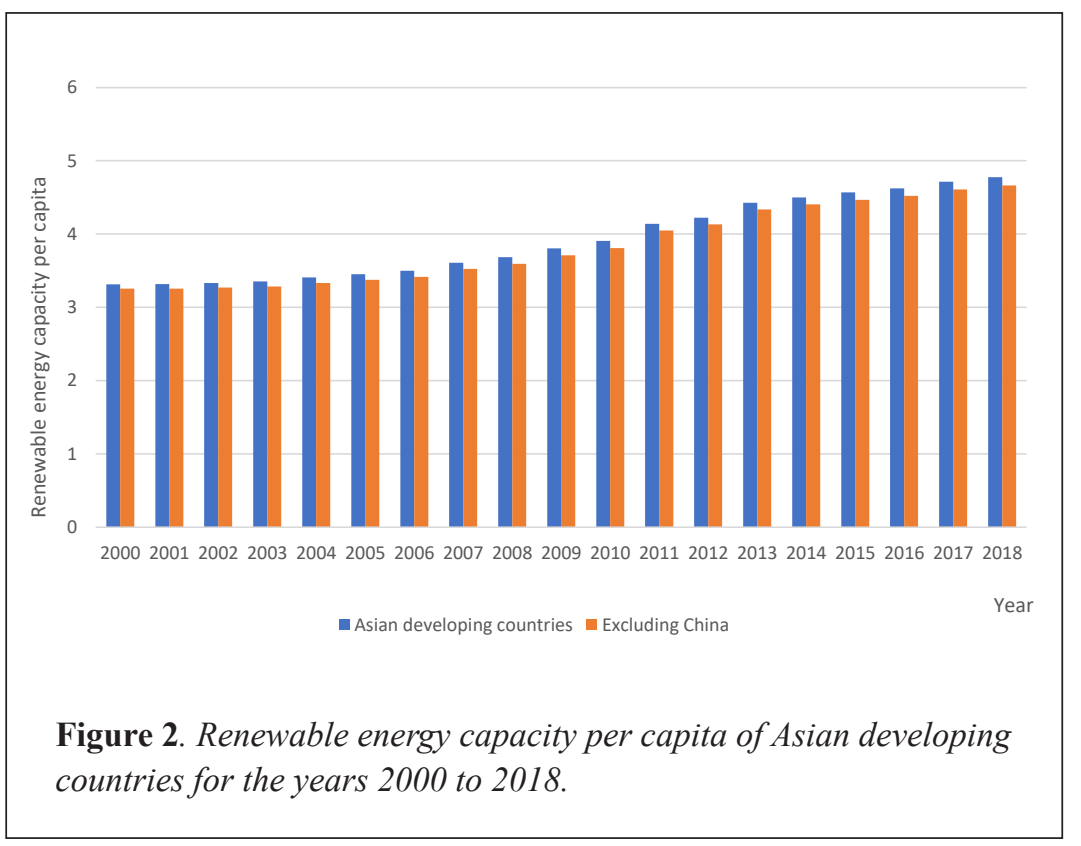

The independent variables, fossil fuel price and $\mathrm{CO}_{2}$ emission, were collected from the World Bank and Global Carbon Atlas websites, respectively. The prices of crude oil, coal, and natural gas were then recorded. The total $\mathrm{CO}_{2}$ emissions arising from the use of fossil fuels were measured per capita. Both the independent and dependent variables appeared in natural logarithmic form. Additionally, this study controlled GDP growth, population growth, and unemployment rate, while China and the upper-middle-income countries were included using dummy variables to account for any potential bias that might result from the significant differences among the countries. The description of each variable is summarized in Table 1 . 


\section{Table 1}

Description of the Observed Variables

\begin{tabular}{|c|c|c|}
\hline Variables & Description & Source \\
\hline $\begin{array}{l}\text { LnRenewable } \\
\text { energy }\end{array}$ & $\begin{array}{l}\text { The natural logarithm form of the } \\
\text { maximum generating capacity of power } \\
\text { installations that use renewable sources } \\
\text { to generate electricity, measured in } \\
\text { megawatts. }\end{array}$ & IRENA \\
\hline LnCrude oil & $\begin{array}{l}\text { The natural logarithm form of the } \\
\text { equally weighted average price } \\
\text { of Brent, Dubai, and West Texas } \\
\text { Intermediate crude oil in US\$ per } \\
\text { barrel. }\end{array}$ & World Bank \\
\hline LnCoal & $\begin{array}{l}\text { The natural logarithm form of the coal } \\
\text { price in US\$ per metric ton. }\end{array}$ & World Bank \\
\hline LnNatural gas & $\begin{array}{l}\text { The natural logarithm form of the } \\
\text { natural gas price in US\$ per million } \\
\text { Btu. }\end{array}$ & World Bank \\
\hline $\mathrm{LnCO}_{2}$ & $\begin{array}{l}\text { The natural logarithm form of the } \\
\text { carbon dioxide }\left(\mathrm{CO}_{2}\right) \text { emissions from } \\
\text { the use of fossil fuels, measured in } \\
\text { million tons of } \mathrm{CO}_{2} \text {. }\end{array}$ & $\begin{array}{c}\text { Global } \\
\text { Carbon Atlas }\end{array}$ \\
\hline $\mathrm{LnCO}_{2}$ per capita & $\begin{array}{l}\text { The total carbon dioxide }\left(\mathrm{CO}_{2}\right) \\
\text { emissions divided by the population } \\
\text { of a country. The value is also in the } \\
\text { natural logarithm form. }\end{array}$ & $\begin{array}{c}\text { Global } \\
\text { Carbon Atlas }\end{array}$ \\
\hline GDP growth & $\begin{array}{l}\text { The annual percentage growth rate of } \\
\text { gross domestic product (GDP) at market } \\
\text { prices based on constant local currency. }\end{array}$ & World Bank \\
\hline Population growth & $\begin{array}{l}\text { The annual percentage growth rate of } \\
\text { individuals in a population. }\end{array}$ & World Bank \\
\hline Unemployment & $\begin{array}{l}\text { The percentage of labor force that is } \\
\text { without work but is available for and } \\
\text { seeking employment. }\end{array}$ & World Bank \\
\hline China & $\begin{array}{l}\text { A dummy variable that takes the value } \\
\text { of } 1 \text { if the observed country is China } \\
\text { and } 0 \text { otherwise. }\end{array}$ & - \\
\hline Upper middle & $\begin{array}{l}\text { A dummy variable that takes the value } \\
\text { of } 1 \text { if the observed country is an upper- } \\
\text { middle-income country and } 0 \text { otherwise. }\end{array}$ & World Bank \\
\hline
\end{tabular}




\section{RESULTS}

Table 2 summarizes the descriptive statistics of the variables for Sample 1 and Sample 2, which excludes China. Panel A presents the non-transformed values of the key variables, while Panel B shows the natural logarithmic values of the variables. For Sample 1 , the average renewable energy capacity was at 25,911 megawatts, reaching a maximum capacity of 695,831 megawatts. In Sample 2, the average renewable energy capacity was only 7,183 megawatts, with a maximum capacity of 117,955 megawatts. However, the average renewable energy per capita was about 196 watts, with a maximum value of 2,238.76 watts for both samples.

The average prices of crude oil, coal, and natural gas were US $\$ 62.84$ per barrel, US $\$ 69.22$ per metric ton, and US $\$ 4.68$ per million Btu, respectively. In terms of greenhouse gas emissions, for Sample 1, the average $\mathrm{CO}_{2}$ emission was 733 million tons, or 2.24 tons per capita, while for Sample 2, the average $\mathrm{CO}_{2}$ emission was 220.34 million tons, or 2 tons per capita. In terms of GDP growth, population growth, and unemployment rate, the average values were approximately similar for both samples.

Table 3 presents the mean values of the country-specific variables. Among the 14 developing countries, China, Malaysia, Sri Lanka, and Thailand are upper middle-income countries. Out of these four, China reported the highest renewable energy capacity of 269,375 megawatts or 198.82 per capita. Malaysia reported the highest $\mathrm{CO}_{2}$ emissions per capita of 7.14, followed by China at 5.52 and Thailand at 3.62. On the other hand, India led the lower-middle-income countries with the highest renewable energy capacity of 55,618 megawatts; nevertheless the per capita value was low at 44.63. In contrast, Bhutan's per capital value was 1.611.23. India also had relatively higher $\mathrm{CO}_{2}$ emissions. It ranked fourth after Mongolia, Indonesia, and Vietnam in terms of $\mathrm{CO}_{2}$ emissions per capita.

Table 4 presents the Pearson correlation matrix for the observed variables. Although LnCrude oil and $\mathrm{LnCoal}$ were highly correlated with a coefficient of 0.88 , this was not a problem because these two variables were used in different models. Overall, the correlation matrix suggested that thee regression model did not suffer from serious multicollinearity problems, which was also confirmed using the Variance Inflation Factor (VIF) test (mean VIF value $=1.43$ ). 


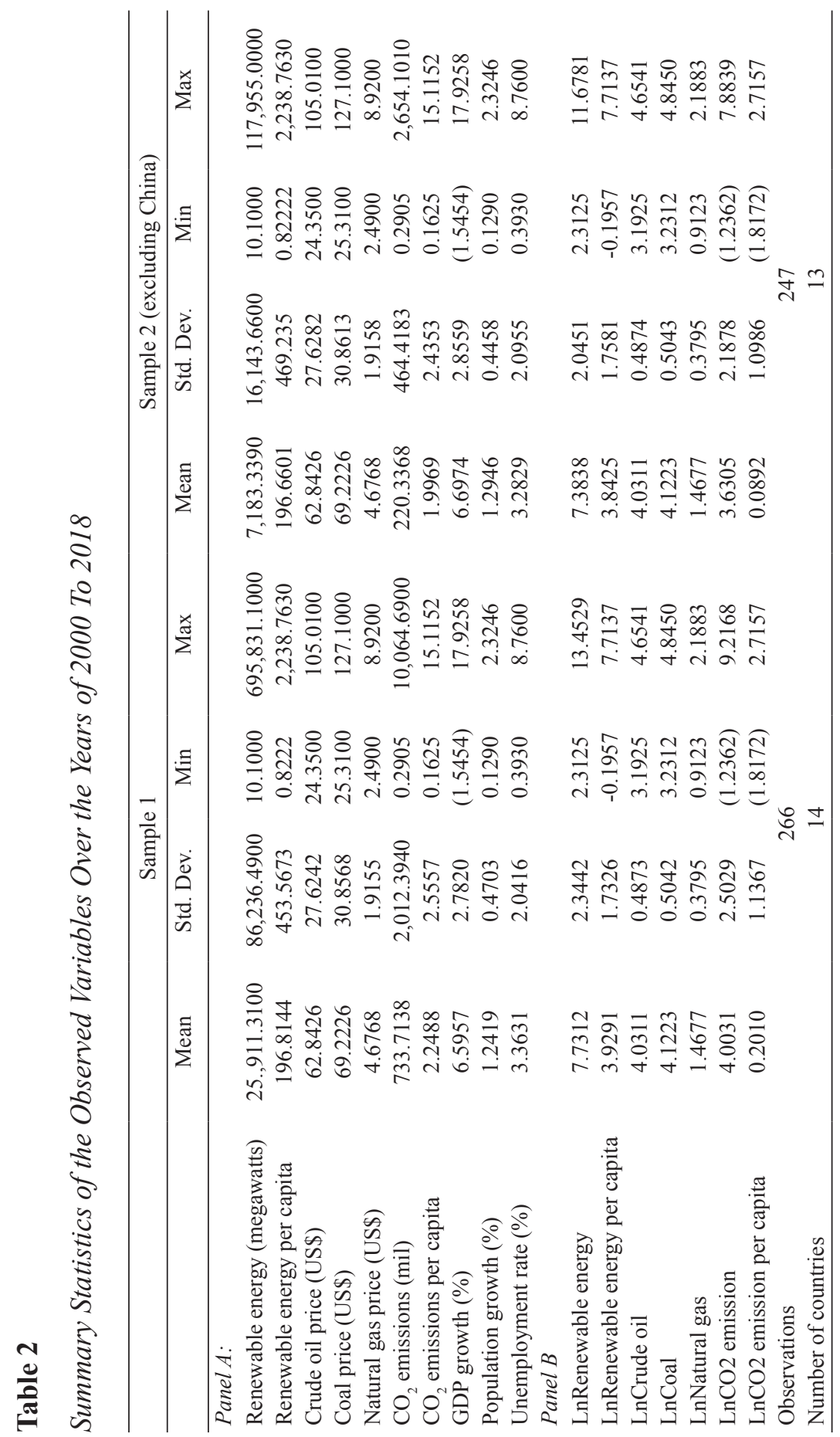




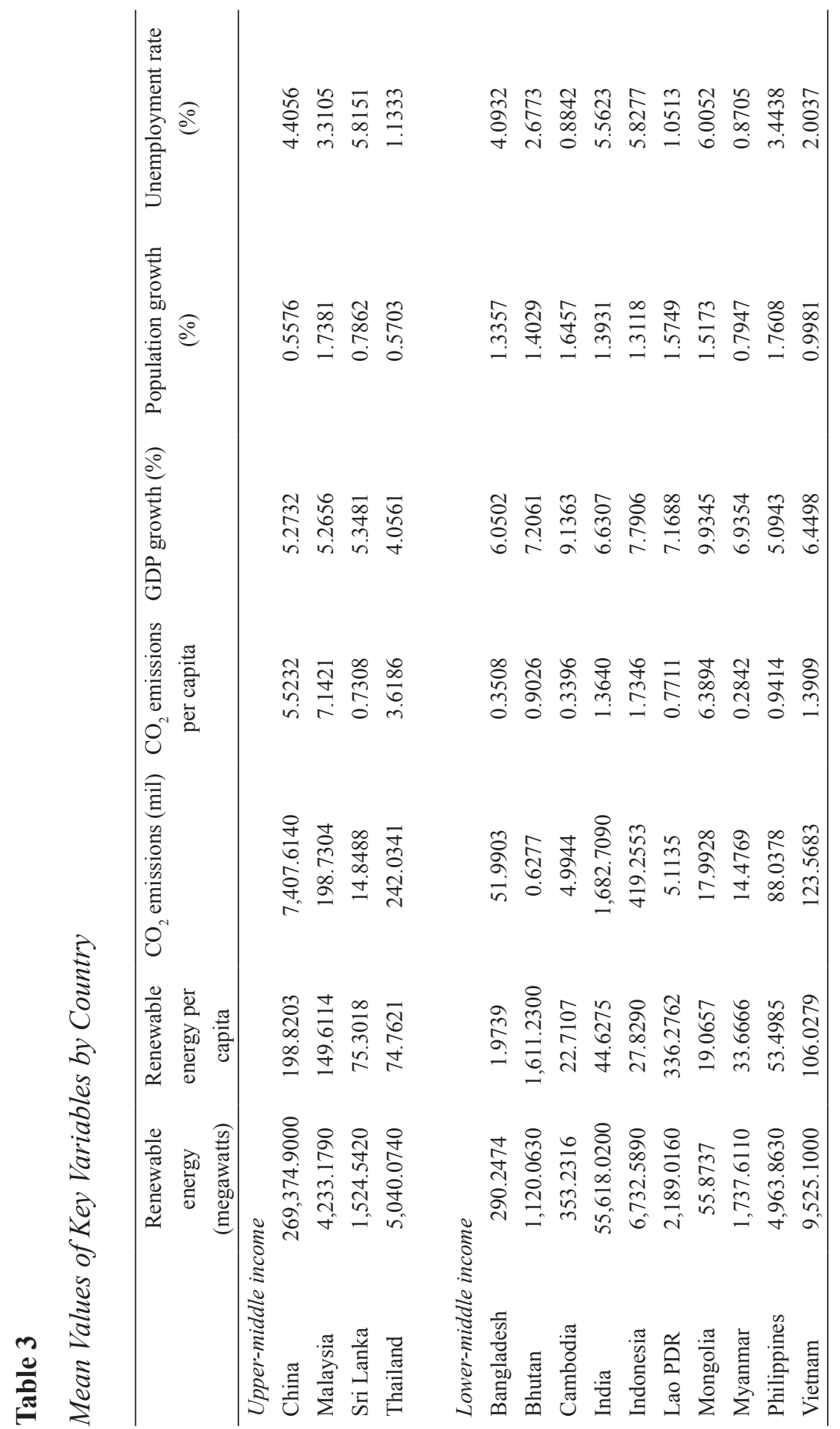




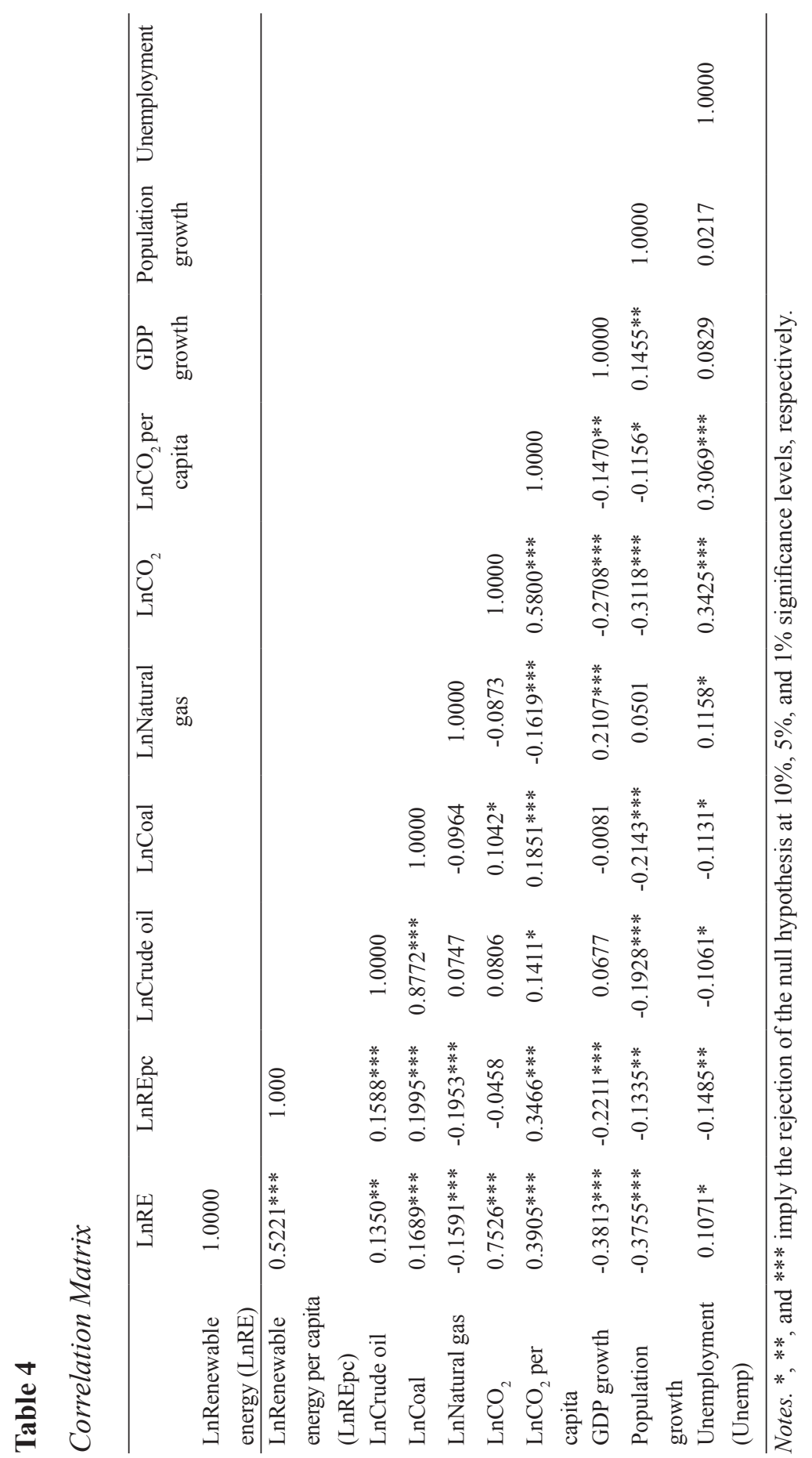


Table 5 reports the estimates of the regression analysis. Based on Models 1 and 2, crude oil and coal prices were positively related to renewable energy capacity. This positive relationship implied that as the prices of crude oil and coal increased, there was a higher demand for renewable energy to substitute fossil fuels (Apergis \& Payne, 2014; Bird et al., 2005; Chang et al., 2009), seemingly driven by cost concerns. It is argued that when fossil fuel prices are high, additional fuel subsidies have to be incurred to continue supplying affordable energy, especially for lower-middle-income countries. Nonetheless, this is deemed as unsustainable in the long run.

Instead, the emphasis should be on allocating subsidies to renewable energy sources to improve the cost competitiveness of renewable energy as compared to non-renewable fossil fuels (Carley, 2009). Gradually, the lower cost of renewable energy would replace fossil fuels like crude oil and coal, which have rising costs due to increased fossil fuel consumption and high risk of resource scarcity (Kaberger, 2018). This is specifically true for Asian developing countries with rapidly growing populations that depend on fossil fuels. These statistics support Hypothesis 1 . On the other hand, natural gas prices were negatively related to renewable energy capacity. A potential explanation for this inverse relationship is that natural gas is a relatively clean fossil fuel as compared to crude oil and coal. This suggests that renewable energy could be more of a complementary energy source (Sadorsky, 2009a; Omri \& Nguyen, 2014).

This study found consistent evidence in support of Hypothesis 2 that $\mathrm{CO}_{2}$ emission was positively related to renewable energy capacity, which was in line with existing studies (Aguirre \& Ibikunle, 2014; Omri \& Nguyen, 2014; Sadorsky 2009a; Salim \& Rafiq, 2012). A consistent positive relationship was reported when $\mathrm{CO}_{2}$ emissions per capita were used as proxy for $\mathrm{CO}_{2}$ emissions (refer to Model 4). Therefore, the higher the $\mathrm{CO}_{2}$ emissions, the more urgent the call becomes for a country to take drastic initiatives to promote and increase the renewable energy capacity. Between fossil fuels and $\mathrm{CO}_{2}$ emission, the effect of $\mathrm{CO}_{2}$ emission on renewable energy outweighed that of fossil fuels.

For the control variables, only GDP growth and population growth were significant. The negative coefficients of GDP growth suggested that higher GDP growth led to lower renewable energy capacity. This discovery contradicted with existing research, such as that of Przychodzen and Przychodzen (2020), with evidence from transitional economies in Central and Eastern Europe, Caucasus, and Central Asia. 


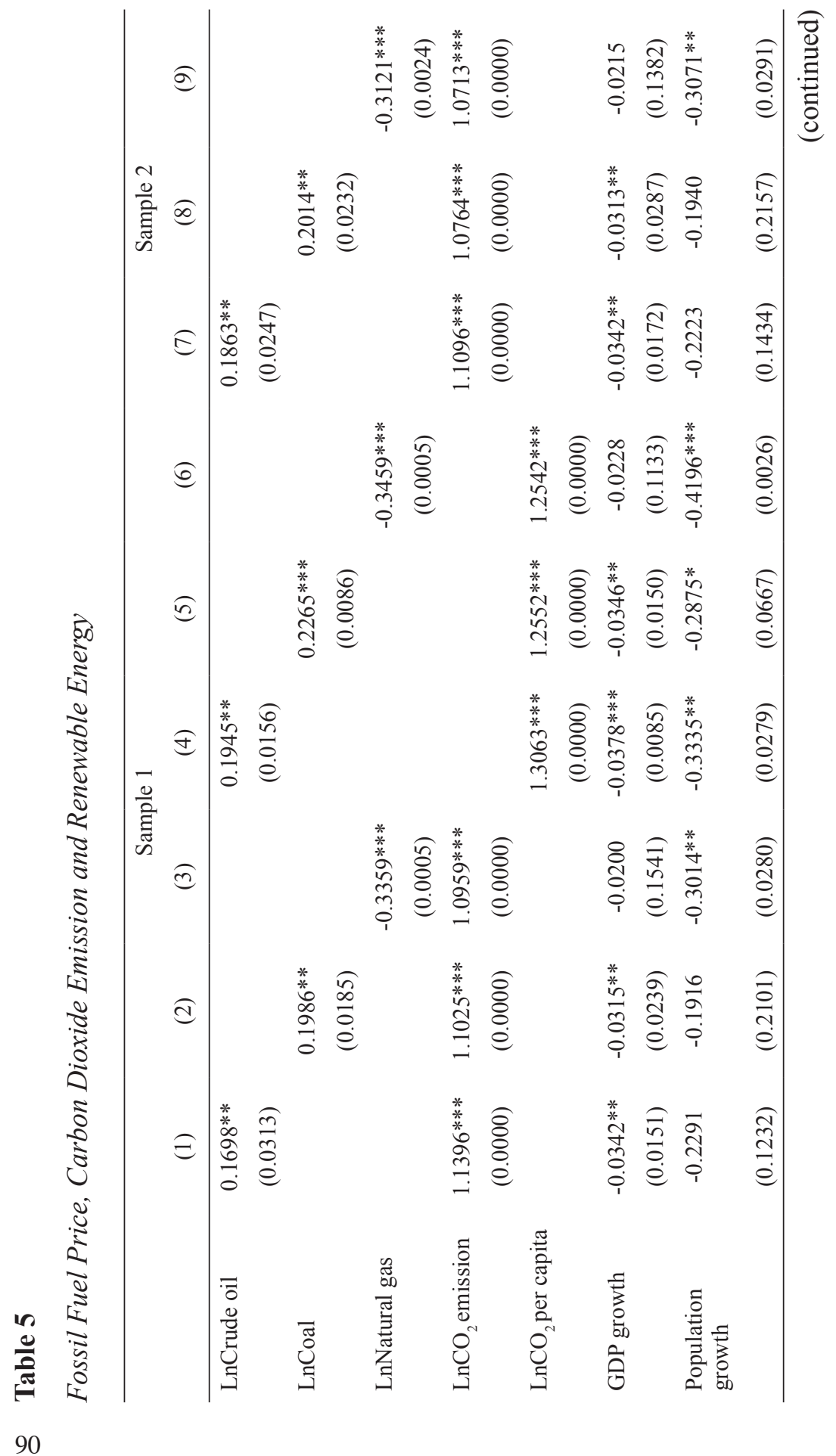




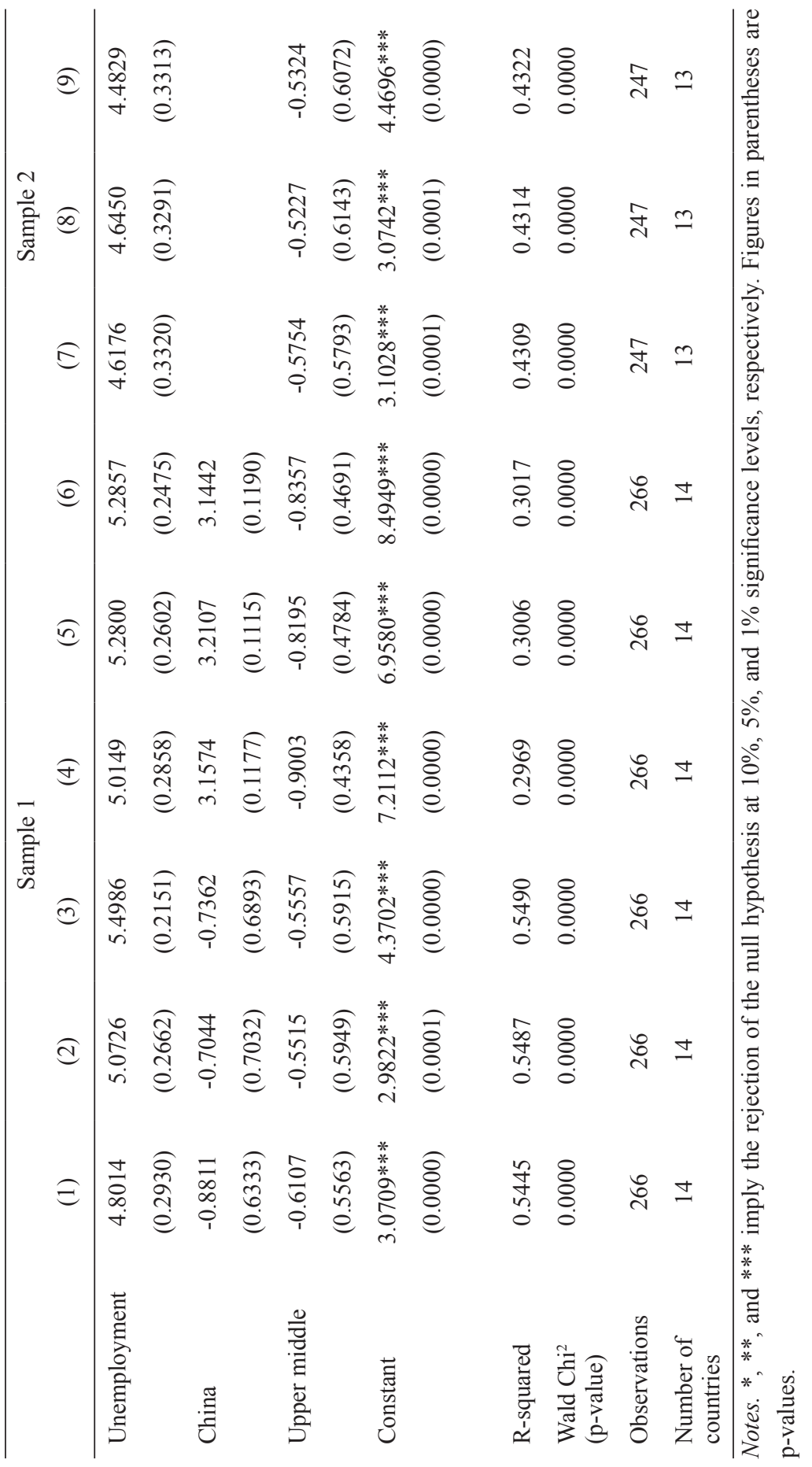


Their argument was consistent with Apergis and Payne (2014), Fan and Hao (2020), Gan and Smith (2011), Marques et al. (2010), and Sadorsky (2009a), whereby high income countries are more likely to invest in renewable energy because these countries have the capacity to afford the cost of renewable energy technologies. It is argued that the conflicting results were mainly due to the different development goals of lower-middle-income countries from those of high-income countries. For example, from Table 3, even though the lower-middleincome countries such as Cambodia (9.13\% ) and Mongolia (9.93\%) reported the highest mean GDP growth, their mean renewable energy capacities were among the lowest in the sample.

Models 3 through 6 indicated that population growth was related to lower renewable energy capacity, which agreed with the work by Aguirre and Ibikunle (2014). High population growth translates to high energy demand. Renewable energy is a new concept for many developing countries, and thus the supply may not be sufficient or consistent enough to meet the demands of an entire country's population. To provide sufficient energy supply, these countries must depend on fossil fuels, which are more affordable, instead of renewable energy. The analysis was then repeated using Sample 2, which excluded China. The results are reported in Models 7 through 9. The analysis was also repeated using the natural logarithm of renewable energy capacity per capita as the dependent variable. Consistently, the results provided evidence in support of Hypotheses 1 and 2. Although the results are not included here for brevity, they are available upon request.

Table 6 reports the results of the sub-sample analysis to control any potential bias due to differences in the countries' size and income levels. The regression analysis was repeated using the lower-middleincome countries, upper middle-income countries, and upper middleincome countries excluding China. Consistently, results from these three sub-samples were in line with those reported in Table 5. Therefore, it can be concluded that the capacity of renewable energy increases when the fossil fuels become more expensive, especially crude oil and coal. In simple terms, cost disadvantage is a significant concern. $\mathrm{CO}_{2}$ emissions are another significant reason for these countries to increase renewable energy capacity, which would also mean increasing investment in renewable energy. 


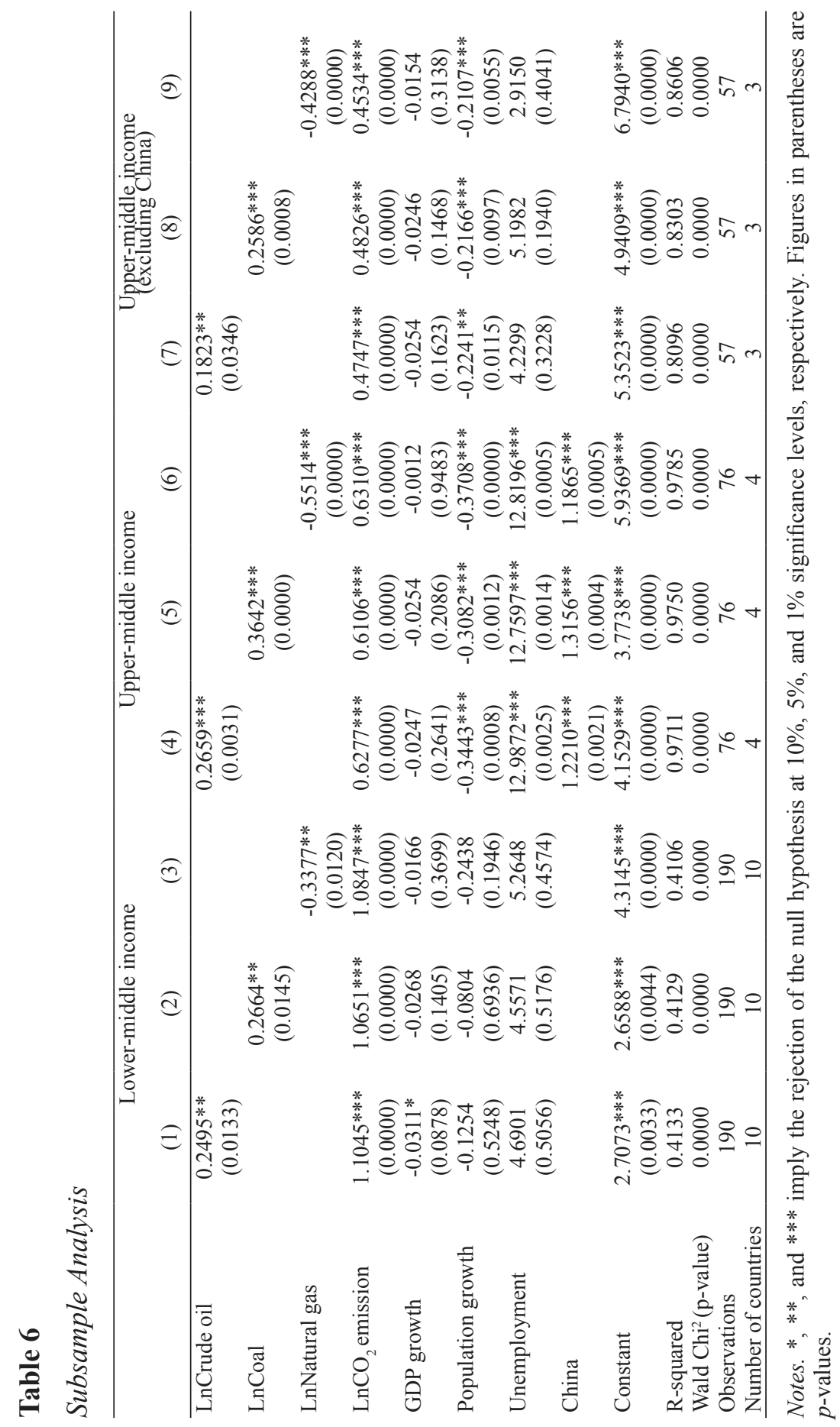




\section{CONCLUDING REMARKS}

Even though Asia has great potential for renewable energy resources, the potential is relatively untapped, particularly among developing countries that are highly dependent on fossil fuels for energy. This mainly results from cost disadvantage. In addition, $\mathrm{CO}_{2}$ emissions are high in these countries. This study shows that fossil fuel prices and $\mathrm{CO}_{2}$ emission provide significant motivation for the adoption of renewable energy, which can substitute crude oil or coal but not for natural gas, for both the upper-middle-income and lower-middleincome countries. The findings further supported the call to reduce fossil fuel dependency and $\mathrm{CO}_{2}$ emissions.

Policymakers should revisit the existing fossil fuel subsidies regulations and respond to the global call to remove fossil fuel subsidies progressively so that fossil fuels are no longer a cheaper energy alternative. Instead, the subsidies should be allocated to finance investment in renewable energy development to increase the cost competitiveness of renewable energy sources. Lower cost translates to better investment returns and could attract renewables investment from the private sector. However, a lack of legislation would discourage investment in renewable energy from the private sector. This paper proposes that governments and policymakers consider stakeholders' interests and shareholders' protections in their decisions to attract not only local investments from the private sector but also foreign investment.

Next, this study found that high $\mathrm{CO}_{2}$ emission led to high renewable energy capacity. It is argued that these developing countries are under pressure to decrease their high $\mathrm{CO}_{2}$ emissions due to environmental concerns. However, the transition to renewable energy is still slow. Therefore, the second call for legislative change lies in the importance of developing policies and regulations that restrict greenhouse gas emissions to motivate the adoption of renewable energy to mitigate the adverse consequences of climate change.

Note that due to data limitations, the study only included 14 Asian developing countries. Thus, it is recommended for future studies to consider more Asian countries in the sample of examination. Future studies can also conduct a comparison study between developing and developed countries and/or examine renewable energy by types such as wind, hydro, geothermal, biomass, and others. 


\section{ACKNOWLEDGMENT}

This research received no specific grant from any funding agency.

\section{REFERENCES}

Aguirre, M., \& Ibikunle, G. (2014). Determinants of renewable energy growth: A global sample analysis. Energy Policy, 69, 374-384.

Apergis, N., \& Payne, J. E. (2014). Renewable energy, output, $\mathrm{CO}_{2}$ emission, and fossil fuel prices in Central America: Evidence from a nonlinear panel smooth transition vector error correction model. Energy Economics, 42, 226-232.

Bird, L., Bolinger, M., Gagliano, T., Wiser, R., Brown, M., \& Parsons, B. (2005). Policies and market factors driving wind power development in the United States. Energy Policy, 33(11), $1397-1407$.

Carley, S. (2009). State renewable energy electricity policies: An empirical evaluation of effectiveness. Energy Policy, 37(8), 3071-3081.

Chang, T. H., Huang, C. M., \& Lee, M. C. (2009). Threshold effect of the economic growth rate on the renewable energy development from a change in energy price: Evidence from OECD countries. Energy Policy, 37, 5796-5802.

Gan, J. B., \& Smith, C. T. (2011). Drivers for renewable energy: A comparison among OECD countries. Biomass and Bioenergy, $35,4497-4503$.

Eckstein, D., Künzel, V., Schafer, L., \& Winges, M. (2019, December 4). Global climate risk index 2020. Who suffers most from extreme weather events? Weather-related loss events in 2018 and 1999 to 2018. https://germanwatch.org/sites/germanwatch. org/files/20-2-01e\%20Global\%20Climate\%20Risk\%20 Index\%202020_10.pdf

Fan, W., \& Hao, Y. (2020). An empirical research on the relationship amongst renewable energy consumption, economic growth and foreign direct investment in China. Renewable Energy, 146, 598-609.

Gozgor, G., Mahalik, M. K., Demir, E., \& Padhan, H. (2020). The impact of economic globalization on renewable energy in the OECD countries. Energy Policy, 139, 111365. 
International Energy Agency. (2020). Energy subsidies: Tracking the impact of fossil-fuel subsidies. https:/Www.iea.org/topics/ energy-subsidies

International Renewable Energy Agency. (2020, March 31). Renewable capacity statistics 2020. https://www.irena.org/ publications/2020/Mar/Renewable-Capacity-Statistics-2020

Kariuki, D. (2018, January 25). Barriers to renewable energy technologies development. Energy Today. https://doi.10.1515/ energytoday-2018-2302

Kaberger, T. (2018). Progress of renewable electricity replacing fossil fuels. Global Energy Interconnection, 1, 48-52.

Marques, A. C., Fuinhas, J. A., \& Manso, J. R. P. (2010). Motivations driving renewable energy in European countries: A panel data approach. Energy Policy, 38, 6877-6885.

Omri, A., \& Nguyen, D. C. (2014). On the determinants of renewable energy consumption: International evidence. Energy, 72, 554-560.

Przychodzen, W., \& Przychodzen, J. (2020). Determinants of renewable energy production in transition economies: A panel data approach. Energy, 191, 116583.

Rustemoglu, H., \& Andres, A. R. (2016). Determinants of $\mathrm{CO}_{2}$ emissions in Brazil and Russia between 1992 and 2011: A decomposition analysis. Environmental Science and Policy, $58,95-106$.

Sadorsky, P. (2009a). Renewable energy consumption, $\mathrm{CO}_{2}$ emissions and oil prices in the G7 countries. Energy Economics, 31, 456-462.

Sadorsky, P. (2009b). Renewable energy consumption and income in emerging economies. Energy Policy, 37(10), 4021-4028.

Salim, R. A., \& Rafiq, S. (2012). Why do some emerging economies proactively accelerate the adoption of renewable energy? Energy Economics, 34, 1051-1057.

Sisodia, G. S., \& Soares, I. (2014). Panel data analysis for renewable energy investment determinants in Europe. Applied Economics Letters, 22, 397-401. 